\author{
mgr inż. Anna STEC \\ Wydział Finansów, Uniwersytet Ekonomiczny w Krakowie \\ e-mail: stec.anna.m@gmail.com \\ mgr Konrad SARZYŃSKI \\ Wydział Ekonomii i Stosunków Międzynarodowych, Uniwersytet Ekonomiczny w Krakowie \\ e-mail: konradsarzynski@gmail.com
}

DOI: $10.15290 /$ ose.2017.06.90.16

\title{
CENTRA HANDLOWE A GOSPODARKA MIASTA NA PRZYKŁADZIE KRAKOWA
}

\begin{abstract}
Streszczenie
Choć centra handlowe w Polsce pojawily się dopiero po koniec XX wieku, na stałe wpisały się w krajobraz, początkowo dużych, a obecnie również mniejszych, miast w całym kraju. Ostatnie dwie dekady to okres niezwykle intensywnego wzrostu liczby centrów handlowych, a także gwałtownej ewolucji ich formuły, od sklepów towarzyszących hipermarketowi, po ogromne obiekty bliskie samowystarczalności i zdolne do zatrzymania klientów przez wiele godzin, zaspokajając wszystkie ich potrzeby. Celem artykułu jest zbadanie otoczenia krakowskich centrów handlowych pod kątem ich wpływu na strukturę przedsiębiorstw. Dokonano klasyfikacji krakowskich centrów handlowych, następnie na podstawie danych o lokalizacji przedsiębiorstw rozpoznano zmiany w strukturze przedsiębiorstw w ich otoczeniu. Wyniki zwizualizowano z wykorzystaniem oprogramowania GIS. Pozwoliło to zweryfikować hipotezę, że w otoczeniu centrów handlowych funkcjonuje wyższy odsetek przedsiębiorstw: handlowych, gastronomicznych i hotelarskich niż w pozostałych częściach miasta.
\end{abstract}

Słowa kluczowe: centra handlowe, rozwój przestrzenny, lokalizacja przedsiębiorstw

\section{SHOPPING CENTRES AND CITY ECONOMY: THE CASE OF CRACOW}

\section{Summary}

Although shopping centres in Poland appeared only at the end of the twentieth century, they have become an inherent part of the landscape of large, and now also smaller, cities across the country. The past two decades have been a period of tremendous growth in the number of shopping centres, also bringing a rapid evolution of their formulas - from hypermarket stores to large, nearly self-sufficient facilities, catering to almost every need of their customers. The aim of the paper is to examine the surroundings of Cracow shopping centres from the perspective of their impact on the structure of these enterprises. Cracow shopping malls are classified and then, based on location data, changes in the structures of the enterprises in their vicinity are examined. The results are visualized using GIS software. This enables the author to verify the hypothesis that there is a higher percentage of shopping, dining, and hotel businesses in areas adjacent to the shopping centers than in the rest of the city.

Key words: shopping mall, spatial development, business location

JEL Classification: L26, M21 


\section{Wstęp}

Centra handlowe są obecne we wszystkich dużych polskich miastach. Ich rosnaca liczba i rozmiary sprawiają, że stają się istotnymi składnikami miejskiego krajobrazu, a w zależności od swojego charakteru i położenia mogą stymulować koncentrację przedsiębiorstw handlowych i usługowych w swoim otoczeniu, tworząc lub wzmacniając dzielnice handlowe.

Pomimo swojej nowoczesności, centra handlowe czerpią z towarzyszących ludzkości od wieków targowisk bądź bazarów czy posiadających kilkuwiekową tradycję domów towarowych, co szerzej omówiono w niniejszym artykule. Łącząc w sobie te elementy, centra handlowe tworzą atrakcyjne miejsce dla konsumentów, zaspokajając wiele potrzeb, stając się wręcz „świątyniami konsumpcji” [Makowski, 2003]. Jeżeli jednak dążą one do samowystarczalności i zaspokajania możliwie największej liczby potrzeb swoich klientów, czy jest jeszcze miejsce dla przedsiębiorstw poza centrami handlowymi?

Celem artykułu jest zbadanie otoczenia krakowskich centrów handlowych pod kątem ich wpływu na strukturę lokalnej gospodarki Krakowa. Postawiono hipotezę, że w otoczeniu centrów handlowych funkcjonuje wyższy odsetek przedsiębiorstw: handlowych, gastronomicznych i hotelarskich niż w pozostałych częściach miasta.

Do weryfikacji postawionej hipotezy zastosowano dane o profilu działalności i lokalizacji wszystkich podmiotów gospodarczych z siedzibą w Krakowie, aktywnych w dniu 30 czerwca 2015 roku, uzyskanych z Wydziału Rozwoju Miasta Urzędu Miasta Krakowa. Powyższe informacje pochodzą z Krajowego Rejestru Urzędowego Podmiotów Gospodarki Narodowej (REGON). Zostały one poddane analizie z użyciem oprogramowania GIS. Ponadto, wykorzystano dane zastane, pochodzące z Głównego Urzędu Statystycznego oraz oficjalnych stron analizowanych centrów handlowych.

\section{Charakterystyka centrów handlowych}

Centra handlowe wywodzą się od hal targowych czy bazarów, oferując duże skupisko niewielkich punktów handlowych i usługowych w jednym miejscu. Jako najstarszy przykład, stosunkowo bliski dzisiejszej idei centrum handlowego, można podać targowisko w Jerozolimie, funkcjonujące już w 2000 r. p.n.e. [Makowski, 2003]. Owe nagromadzenie wielu niezależnych podmiotów w jednym miejscu to także największa różnica w stosunku do domów towarowych, oferujących często równie szeroki wybór produktów, lecz sprzedawanych pod jedną marką domu towarowego, podczas gdy w centrach handlowych każdy ze sklepów funkcjonuje pod własną marką i najczęściej promuje się oddzielnie [Budner, 2014]. Odwołań do starożytnych targowisk jako przodków współczesnych centrów handlowych nie należy jednak traktować w sposób dosłowny, ze względu na bardzo istotną różnicę w formule ich funkcjonowania. O ile targowiska były przestrzeniami publicznymi, centra handlowe są przestrzeniami prywatnymi, choć nierzadko bardzo zręcznie imitującymi te pierwsze. To z kolei zbliża je bardziej do domów towarowych okresu rewolucji przemysłowej niż do wcześniejszych targowisk [Makowski, 2003]. 
Można zatem uznać, że centra handlowe są najnowszym i być może ostatnim fizycznym etapem ewolucji handlu (w perspektywie przenoszenia wielu aktywności do Internetu i ogromnej popularności sklepów internetowych). Czerpią one jednocześnie z wielu dotychczasowych doświadczeń, łącząc cechy zarówno zamkniętych prywatnych domów towarowych, jak i otwartych oraz ogólnodostępnych targowisk, tworząc w XXI wieku niepowtarzalną $i$ atrakcyjną formę konsumpcji.

Pierwsze centra handlowe powstały około 100 lat temu w Stanach Zjednoczonych, rozpoczynając nową erę w handlu i zmieniając podobnie wygląd miast, jak i zachowania mieszkańców. W Polsce pierwsze centra handlowe zaczęły pojawiać się dopiero pod koniec XX wieku, co w naturalny sposób powoduje, że badania nad tą formą handlu mają w naszym kraju krótszą historię i są mniej zaawansowane niż w Stanach Zjednoczonych.

Sprawiało to kłopoty zwłaszcza w kwestii definicji centrum handlowego, odmiennego od amerykańskiego, funkcjonującego także w innych warunkach niż centra handlowe Europy Zachodniej. Z pomocą przyszły analizy Międzynarodowego Stowarzyszenia Centrów Handlowych. W 2005 roku zaproponowano zdefiniowanie centrum handlowego jako obiektu: handlowego zaplanowanego, wybudowanego i zarządzanego jako jeden podmiot, łączącego lokale handlowe, usługowe i część wspólną, o minimalnej powierzchni najmu $5000 \mathrm{~m}^{2}$ i co najmniej 10 najemcach [Heffner, Twardzik, 2015]. Mikołajczyk wskazuje na jedną z najważniejszych cech centrów handlowych, wyróżniająca te obiekty - wysoki standard robienia zakupów [2009].

W literaturze funkcjonuje kilka popularnych rodzajów klasyfikacji centrów handlowych, w zależności od przyjętego głównego kryterium podziału, np.: powierzchni, obszaru oddziaływania, różnorodności najemców. Najogólniejszą klasyfikacją jest ta dzieląca centra handlowe na tradycyjne i profilowane [Budner, 2014, s. 25]. Tradycyjne centra handlowe skupiają najemców o bardzo szerokim zakresie działalności z rdzeniem w postaci hipermarketu, w pobliżu którego często znajduje się również duży sklep z elektronika. Z kolei, profilowane centra handlowe ograniczają się do jednej branży, np. meblowej czy modowej, oferując jednak wiele specjalistycznych sklepów, często niedostępnych lub dostępnych w mniejszej skali w tradycyjnych obiektach.

W ramach tego podziału można dokonać kolejnej klasyfikacji, a mianowicie w zależności od obszaru wpływu - mogą to być obiekty: osiedlowe, lokalne, regionalne i ponadregionalne [Budner, 2014, s. 35-36]. Ze względu na ogromne zróżnicowanie form, jakie przyjmują centra handlowe, taki podział przestaje być wystarczający i wymaga dalszego uszczegółowienia [Pitt, Musa, 2009]. W polskich warunkach bardzo użyteczny jest podział na generacje centrów handlowych, które szerzej omówiono w następnym podrozdziale.

Jednocześnie interesującym zagadnieniem jest turystyka zakupowa - efekt postępujacej „turystyfikacji” świata. Ściśle wiąże się ona z funkcjonowaniem centrów handlowych, które stają się celem podróży zarówno z okolicznych miejscowości, jak i z odległych części kraju i zza granicy, przynosząc tym samym dochody nie tylko centrom handlowym, ale zarazem miastom dzięki towarzyszącym zakupom wydatkom w innych punktach handlowych czy usługowych [Niemczyk, 2015]. Zdaniem autorów, zyski dla miasta z funkcjonowania galerii handlowych są zagadnieniem bardzo złożonym, wymagającym uwzględnienia wielu kosztów pośrednich (np. większego obciążenia infrastruktury dro- 
gowej czy spadku liczby odwiedzających centra miast o tradycyjnie handlowym charakterze), jednak niezaprzeczalnie zjawisko turystyki zakupowej występuje również w Polsce. Jest to temat wciąż stosunkowo słabo rozpoznany, a badania przede wszystkim skupiają się na przygranicznych miastach [np.: Brzosko-Sermak, 2015; Markiewicz, 2010].

Choć w przeprowadzonej analizie skoncentrowano się na ekonomicznych aspektach wpływu centrów handlowych, należy zaznaczyć, że są to także niezwykle ważne obiekty z punktu widzenia socjologii. Zarówno w Stanach Zjednoczonych będących kolebką centrów handlowych, jak i w Polsce stanowią one miejsce licznych, społecznych interakcji [np.: Backes, 1997; Feinberg, Sheffler, Meoli, Rummel, 1989; Makowski, 2003]. Jest to zagadnienie niezmiernie istotne $\mathrm{z}$ racji oddziaływania centrów handlowych na mieszkańców i odwiedzających miasto, a tym samym na samo miasto, lecz ze względu na ograniczenie badania do sfery przedsiębiorstw zostanie ono pominięte.

\section{Centra handlowe w Polsce}

Obserwowany mniej więcej od połowy lat dziewięćdziesiątych XX wieku gwałtowny przyrost liczby centrów handlowych jest odpowiedzią na ogromny popyt na takie obiekty podobnie w największych miastach (na których była skupiona uwaga w pierwszych latach rozwoju centrów handlowych), jak i w tych średnich oraz małych (popularne obecnie niewielkie galerie handlowe). Tak ogromna i stale rosnąca popularność centrów handlowych, jak wskazuje Makowski, jest spowodowana m.in. niedosytem polskiego społeczeństwa po latach PRL-u. Możliwość zrobienia zakupów w coraz to większych obiektach z setkami sklepów była (i wciąż jest) konsumpcyjnym spełnieniem marzeń wielu Polaków, a same centra handlowe można metaforycznie ująć „drzwiami do konsumpcyjnego raju" [Makowski, 2003, s. 11].

W rozwoju polskich centrów handlowych wyróżnia się generacje, obrazujące najważniejsze przemiany, jakie zachodziły w ich: rozmiarze, doborze najemców i konstrukcji (tabela 1.).

Część z centrów handlowych cechuje się innym zestawem oferowanych usług, wynikających z: lokalnej specyfiki rynku, możliwości zabudowy wybranego miejsca czy chęci wyróżnienia się. Na przykład w położonej centralnie Galerii Krakowskiej nie ma kina, za to są dostępne siłownia i powierzchnie biurowe.

Centra handlowe, powstające w centralnych częściach miast, moga pozytywnie wpływać na postrzeganie tych dzielnic przez mieszkańców, czego przykładem jest Stary Browar w Poznaniu, który, według blisko $62 \%$ ankietowanych, pozytywnie zmienił wizerunek centrum Poznania [Mikołajczyk, 2009]. Jest to zatem przykład udanej rewitalizacji, zmieniającej tereny przemysłowe w atrakcyjne miejsca: zakupów, rozrywki i spotkań. 
TABELA 1.

Generacje centrów handlowych w Polsce

\begin{tabular}{|c|l|l|l|}
\hline Generacja & \multicolumn{1}{|c|}{$\begin{array}{c}\text { Pierwsi } \\
\text { przedstawi- } \\
\text { ciele }\end{array}$} & Lokalizacja & \multicolumn{1}{c|}{$\begin{array}{c}\text { Powierzchnia, liczba i rodzaj } \\
\text { sklepów }\end{array}$} \\
\hline I & $\begin{array}{c}\text { Połowa lat 90. } \\
\text { XX wieku }\end{array}$ & $\begin{array}{l}\text { Obrzeża } \\
\text { miast }\end{array}$ & $\begin{array}{l}\text { 5-8 tys. m² } \\
\text { Niewielka liczba sklepów towarzyszacych } \\
\text { hipermarketowi, małe punkty usługowe } \\
\text { (np.: pralnia, dorabianie kluczy), restau- } \\
\text { racja typu fast food }\end{array}$ \\
\hline II & Koniec lat 90. & $\begin{array}{l}\text { Obrzeża } \\
\text { XXast }\end{array}$ & $\begin{array}{l}\text { Hipermarket wraz z towarzyszacymi skle- } \\
\text { pami wielkopowierzchniowymi, szeroka } \\
\text { oferta gastronomiczna i rozrywkowa, więk- } \\
\text { sze punkty usługowe (np.: salon fryzjerski } \\
\text { lub kosmetyczny, biuro podróży, miejsce } \\
\text { zabaw dla dzieci, salon gier) }\end{array}$ \\
\hline III & Początek XXI & $\begin{array}{l}\text { Centralne } \\
\text { dzielnice } \\
\text { miast }\end{array}$ & $\begin{array}{l}\text { Rozbudowana czę́́ sportowo-rekreacyjna, } \\
\text { kompleks kinowy, bogata oferta gastro- } \\
\text { nomiczna, obecność luksusowych marek }\end{array}$ \\
\hline IV & Współcześnie & $\begin{array}{l}\text { Najczęściej } \\
\text { centralne } \\
\text { dzielnice } \\
\text { miast }\end{array}$ & $\begin{array}{l}\text { Poza funkcją handlową i rozrywkowa (roz- } \\
\text { budowana często np. o galerie sztuki czy } \\
\text { amfiteatry), także biurowa i hotelowa, roz- } \\
\text { budowane obiekty wypoczynkowe (parki, } \\
\text { fontanny, kregielnie, ścianki wspinaczko- } \\
\text { we), podstawowe usługi medyczne - imi- } \\
\text { acja przestrzeni publicznej }\end{array}$ \\
\hline & W przyszłości & $\begin{array}{l}\text { Niezależnie } \\
\text { od miasta? } \\
\text { centrum handlowe również o funkcje } \\
\text { mieszkalne, dążąca do samowystarczal- } \\
\text { ności }\end{array}$ \\
\hline
\end{tabular}

Źródło: opracowanie własne na podstawie: [Budner, 2014; Heffner Twardzik, 2015; Mikołajczyk, 2009, 2012; Sławińska, 2008].

Centra handlowe z I i II generacji wciąż funkcjonują i nadal mogą powstawać. Kolejne generacje nie zastępowały poprzednich, a jedynie rozbudowywały koncepcję centrów handlowych [Budner, 2014, s. 26]. O ile I i II generacja nie odgrywają już znaczącej roli w największych miastach, gdzie w zestawieniu z najnowszymi, ogromnymi obiektami trudno nazwać je pełnoprawnymi centrami handlowymi, to mogą one wciąż pełnić funkcję ważnych obiektów handlowych w mniejszych miejscowościach.

Trzecia generacja może być utożsamiana z typowym centrum handlowym. Klienci mogą skorzystać z bogatej oferty gastronomicznej oraz pójść do kina, a liczba sklepów zapewnia duży wybór wszelkiego rodzaju dóbr.

Czwarta generacja to nowoczesne centra handlowe, które cechują się rozszerzoną ofertą dla klientów (m.in. zaspokajająca potrzeby kulturalne czy zdrowotne). Dodatkowo, przyciaga ona inna grupę, nieobecną w poprzednich generacjach - pracowników firm wynajmujących powierzchnie biurowe na jej terenie i gości hotelowych. Ze względu 
na mnogość zaspokajanych potrzeb, centra handlowe czwartej generacji to potężne obiekty dominujące często nie tylko w swoim bezpośrednim otoczeniu, ale również w całym mieście.

Centra handlowe piątej generacji wciąż jeszcze są w pewnym stopniu wizją przyszłości, samowystarczalnego „miasta w mieście”. Teoretycznie mieszkańcy nie musieliby wychodzić poza jej teren, na którym znajdowałyby się także podstawowe placówki medyczne czy oświatowe. Prawdopodobnie z racji bardzo dużej powierzchni, lokalizacja takiego centrum handlowego wymagałaby albo miejsca poza miastem, lecz położonego bardzo korzystnie w stosunku do infrastruktury drogowej bądź kolejowej, albo też na terenach zdegradowanych, będąc formą rewitalizacji całej dzielnicy poprzemysłowej lub terenów po dużych zakładach. Heffner i Twardzik wskazuja, że za centrum handlowe piątej generacji można uznać Silesia City Center w Katowicach z uwagi na przynależący do niej budynek biurowy i osiedle mieszkaniowe [Heffner, Twardzik, 2015], co teoretycznie spełnia wymogi galerii $\mathrm{V}$ generacji. Jednak rozproszenie budynków i umiejscowienie na obszarze o dużej gęstości zabudowy przesądza o tym, że katowickie centrum handlowe nie jest odrębna, wyraźnie kontrastująca całością, zdolną do zaspokajania wszystkich podstawowych potrzeb klientów i mieszkańców w jednym miejscu.

\section{Obszar badań}

Kraków jest silnie rozwijającym się ośrodkiem miejskim, o czym świadczy dynamika przyrostu zarówno liczby mieszkańców, jak i liczba nowo zarejestrowanych podmiotów gospodarczych. W końcu grudnia 2015 roku liczba mieszkańców ludności Krakowa wynosiła 761069 mieszkańców, co stanowiło 22,6\% ogólnej liczby ludności województwa małopolskiego. Począwszy od 2008 roku, przyrost naturalny jest dodatni, zaś od 2009 roku saldo migracji wewnętrznych i zewnętrznych jest dodatnie [Raport o stanie miasta, 2015].

O znaczeniu stolicy Małopolski świadczy również fakt, że już w 2003 roku została podjęta uchwała o utworzeniu Krakowskiego Obszaru Metropolitalnego [Uchwała..., 2003], składającego się z 51 gmin na terenie województwa małopolskiego. Jednak kwestia metropolitalności jest w znacznej mierze subiektywna, natomiast zarówno liczba polskich metropolii, jak i ich znaczenie zależy od przyjętej metodologii oraz opinii badacza [np. Hołuj, 2015]. Jednocześnie nie jest jednoznaczny kształt Krakowskiego Obszaru Metropolitalnego, zależny od przyjętych kryteriów delimitacji oraz koncentracji bardziej na administracyjnych bądź praktycznych aspektach funkcjonowania metropolii [Sarzyński, 2016]. Równoległe posługiwanie się licznymi podziałami, stosującymi odmienną metodykę, stanowi wyzwanie przy próbie porównywania badań przeprowadzonych na ich podstawie, a zarazem może prowadzić do mylnej interpretacji wyników.

Na przestrzeni ostatnich lat można zaobserwować stabilny, stały wzrost liczby przedsiębiorstw działających na terenie Krakowa (wykres 1.). Na koniec grudnia 2015 roku na terenie Krakowa zarejestrowano 130233 podmioty gospodarki narodowej z siedzibą w 
Krakowie. W latach 2010-2015 liczba przedsiębiorstw z sektora publicznego pozostawała na stosunkowo stabilnym poziomie, malejąc z 1472 do 1 434, stanowiąc jedynie 1,1\% wszystkich przedsiębiorstw w 2015 roku. Liczba prywatnych przedsiębiorstw rosła z kolei w szybkim tempie, ze 114215 w 2010 roku do 126562 w 2015 roku. Świadczy to z jednej strony o bardzo dużej przedsiębiorczości mieszkańców, z drugiej zaś o stale umacniającej się roli miasta w regionie, co dodatkowo potwierdza fakt, że nie jest to wzrost powodowany jedynie wzrostem liczby mieszkańców - ta na przestrzeni lat 2010-2015 nie odnotowywała corocznych przyrostów, a w 2012 i 2015 roku nawet jej spadek.

\section{Liczba ludności i zarejestrowanych przedsiębiorstw w Krakowie w latach 2010-2015}

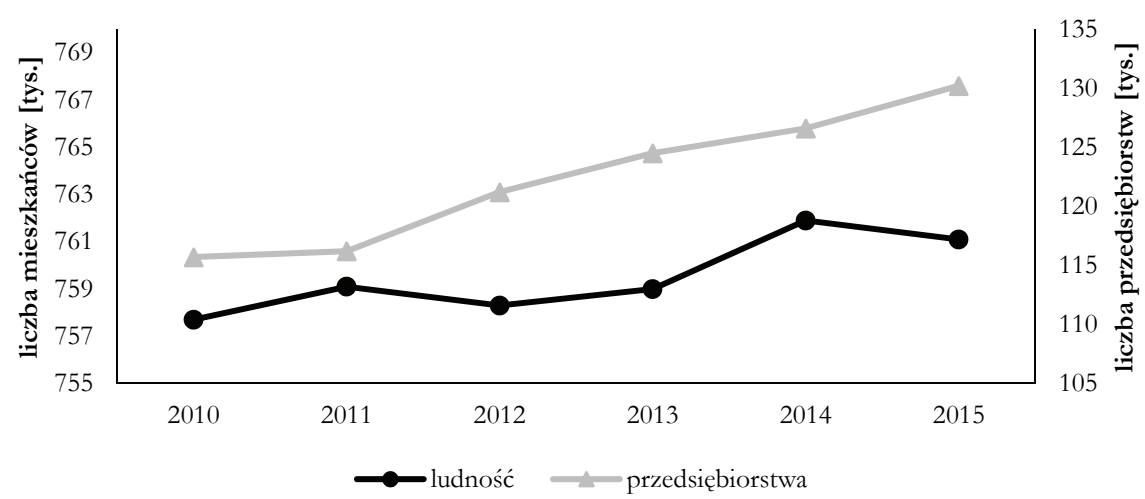

Źródło: opracowanie własne na podstawie: [Raport o stanie miasta, 2015].

Według corocznie przeprowadzanego rankingu THOLONS dotyczącego 100 największych światowych centrów outsourcingowych, Kraków zajmuje dziewiąte miejsce na świecie oraz pierwsze miejsce w Europie. W raporcie tym, obok Krakowa, znalazły się jeszcze inne polskie miasta, takie jak Warszawa czy Wrocław, ale uplasowały się na odległych pozycjach. Raport ten stanowi ramy rozwoju i ukazuje kierunek ekspansji i wyboru lokalizacji przez czołowe światowe firmy [Tholons 2015 ..., 2014]. Sytuacja przedstawiona $\mathrm{w}$ raportach jest silnie skorelowana $\mathrm{z}$ sytuacja gospodarcza miasta, w tym z ilością podmiotów gospodarczych. W związku z powyższym, coraz większa liczba osób znajduje pracę w Krakowie, a to wiąże się z rosnącym popytem na nieruchomości mieszkalne.

Niejako potwierdzeniem rozwoju gospodarczego Krakowa jest także prognoza autorów raportu „Przestrzeń życia Polaków”, który wskazuje, że do 2035 roku tylko dwa polskie miasta, tj. Kraków i Warszawa, zyskaja mieszkańców, jak również stanowią główny potencjał i motor rozwojowy całego kraju, przyczyniając się do wzrostu PKB [Pržestrzén życia Polaków, 2014]. Ocenę skali koncentracji zasobów i mieszkańców wokół Krakowa utrudnia jednak nieprzystawalność podziałów administracyjnych i funkcjonalnych, przywołana przy analizie Krakowa jako metropolii. W rzeczywistości 
funkcjonalny obszar Krakowa (przez który rozumie się metropolię) obejmuje coraz więcej okolicznych gmin, a często bardzo gwałtownie rosnąca w nich liczba mieszkańców powinna być postrzegana jako wzrost liczby mieszkańców funkcjonalnego Krakowa.

\section{Krakowskie centra handlowe}

$\mathrm{Na}$ terenie Krakowa znajduje się dwanaście obiektów, które zostały zaklasyfikowane do analizy jako centra handlowe (tabela 2.). Wśród nich najliczniejsze są centra handlowe I i IV generacji (po czterech przedstawicieli). Z kolei, III generacja ma tylko jednego przedstawiciela - Galerię Plaza.

TABELA 2.

Krakowskie centra handlowe

\begin{tabular}{|c|c|c|c|c|c|c|}
\hline Lp. & Nazwa & $\begin{array}{c}\text { Data zało- } \\
\text { żenia }\end{array}$ & $\begin{array}{l}\text { Gene- } \\
\text { racja }\end{array}$ & $\begin{array}{l}\text { Powierz- } \\
\text { chnia } \\
\text { najmu }\end{array}$ & $\begin{array}{l}\text { Liczba na- } \\
\text { jemców }\end{array}$ & $\begin{array}{l}\text { Liczba miejsc } \\
\text { parkingowych }\end{array}$ \\
\hline 1. & Bonarka City Center & 2009 & IV & 92999 & 270 & 3200 \\
\hline 2. & $\begin{array}{l}\text { Centrum Handlowe Czy- } \\
\text { żyny }\end{array}$ & 2002 & I & 31015 & 71 & 865 \\
\hline 3. & $\begin{array}{l}\text { Centrum Handlowe Kro- } \\
\text { kus }\end{array}$ & 1997 & II & $30000^{*}$ & 55 & 1100 \\
\hline 5. & Centrum Handlowe M1 & 2001 & II & 48606 & 111 & 1358 \\
\hline 7. & Galeria Bronowice & 2013 & IV & 64076 & 150 & 2400 \\
\hline 9. & $\begin{array}{l}\text { Galeria Handlowa Solvay } \\
\text { Park }\end{array}$ & 2007 & I & 14000 & 42 & 200 \\
\hline 10. & Galeria Kazimierz & 2005 & IV & 36200 & 150 & 1460 \\
\hline 11. & Galeria Krakowska & 2006 & IV & 60000 & 270 & 1400 \\
\hline 12. & Galeria Plaza & 2001 & III & 29423 & 65 & 1420 \\
\hline 13. & King Square & 2010 & I & 13825 & 100 & 550 \\
\hline 14. & $\begin{array}{l}\text { Park Handlowy Zako- } \\
\text { pianka }\end{array}$ & 1998 & II & 58000 & 86 & 2200 \\
\hline 18. & Tesco Kraków & bd. & I & 6200 & 41 & 1000 \\
\hline \multicolumn{4}{|c|}{ Lączna liczba } & 484344 & 1411 & 17153 \\
\hline
\end{tabular}

* powierzchnia ogólna; bd. - brak danych

Źródło: opracowanie własne.

\section{Materiały i metody}

Podstawowymi materiałami źródłowymi wykorzystanymi w pracy były informacje związane z lokalizacją podmiotów gospodarczych i obiektów handlowych. Pierwsze materiały zostały udostępnione przez Urząd Miasta Krakowa, zaś drugie były wynikiem inwentaryzacji dokonanej przez autorów w przestrzeni miejskiej, według kryteriów przyjętych na podstawie analizy literatury. 
W tym miejscu należy wspomnieć o zaistniałych problemach. Otrzymana baza danych zawiera jedynie podmioty gospodarcze zarejestrowane na terenie Krakowa i nie uwzględnia przedsiębiorstw zarejestrowanych gdzie indziej, lecz aktywnie działających na rynku krakowskim. Wykorzystywane dane nie sa kompletne, jednak reprezentuja ponad $99 \%$, zatem poziom braków można uznać za nieistotny.

RYSUNEK 1.

\section{Położenie centrów handlowych wraz z analitycznymi okręgami}

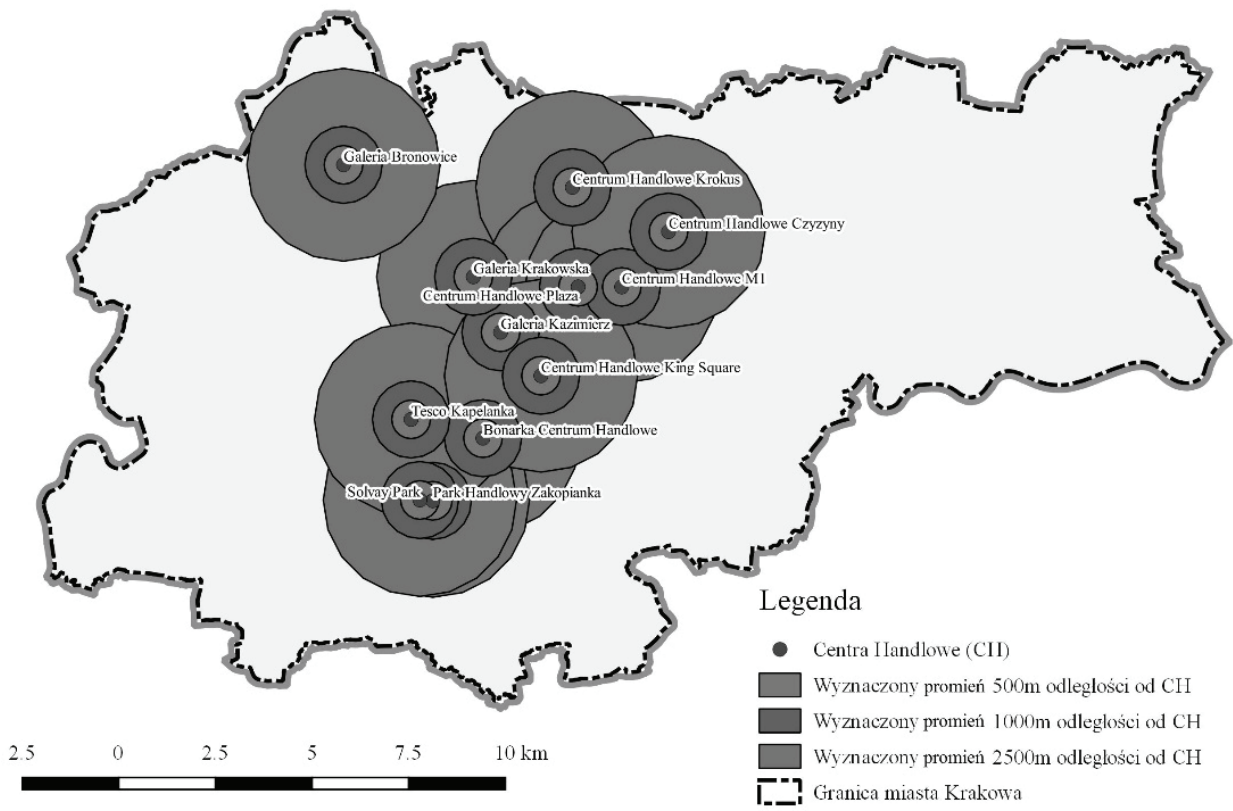

Źródło: opracowanie własne.

Kolejnym etapem było wczytanie materiałów źródłowych do programu GIS, gdzie zostały wykonane dalsze prace. Analizę otoczenia centrów handlowych przeprowadzono wyznaczając trzy okręgi z centrum handlowym w ich środku - odpowiednio o promieniu: 500, 1000 i $2500 \mathrm{~m}$ (rysunek 1.). Wybór wielkości okręgów był subiektywny i wynikał z chęci wyszczególnienia przedsiębiorstw bezpośrednio dostępnych pieszo z centrum handlowego $(500 \mathrm{~m})$, w dalszym sąsiedztwie $(1000 \mathrm{~m})$ oraz w szerzej rozumianym otoczeniu $(2500 \mathrm{~m})$. Przyjmując w uproszczeniu prędkość chodu człowieka jako $5 \mathrm{~km} / \mathrm{h}$, odpowiada to obszarowi dostępnemu dla pieszego w: 6,12 i 30 minut.

Autorzy są świadomi, że odległość wyrażana promieniem jest dalece niedoskonała do wyznaczania dostępności pieszej, a różnice w stosunku do rzeczywistej odległości, uwzględniającej zagospodarowanie przestrzeni, mogą być znaczne [Książkiewicz, 2015]. 
Jednak ze względu na fakt, że jest to jedynie uproszczone ujęcie na potrzeby dalszej analizy, zdecydowano się na takie podejście, będące kompromisem między użytecznością a dokładnością.

Następnym krokiem była analiza porównawcza, mająca na celu pokazanie rozmieszczenia podmiotów gospodarczych w wyłonionych okręgach. Wykorzystano narzędzie przycięcia warstwy przedsiębiorstw do wyznaczonej granicy buforów (okręgów), czego wynik prezentuje rysunek 2 .

RYSUNEK 2.

\section{Lokalizacja przedsiębiorstw w zaproponowanych okręgach}



Źródło: opracowanie własne.

Z reguły bezpośrednie otoczenie centrów handlowych cechowało się dużą liczbą przedsiębiorstw, za wyjątkiem Bonarki oraz M1, które nie tylko w swoim bezpośrednim otoczeniu posiadały najmniej aktywnych podmiotów - odpowiednio: 76 i 119 (wykres 2.) - ale również były one silnie skoncentrowane, co skutkowało „pustymi” wewnętrznymi okręgami (rysunek 2.). Park Handlowy Zakopianka, Centrum Handlowe Plaza, Galeria Bronowice oraz Solvay Park także znajduja się na obszarze o stosunkowo niewielkiej liczbie aktywnych przedsiębiorstw, co wynika $z$ ich usytuowania poza ścisłym centrum miasta. W bezpośrednim sąsiedztwie analizowanych centrów handlowych znalazło się 5,47\% wszystkich przedsiębiorstw w Krakowie, w odległości do $1000 \mathrm{~m}$ 26,14\%, zaś w dalszym otoczeniu (do 2500 m) 82,01\% (wykres 3.). 
WYKRES 2.

Liczba przedsiębiorstw w otoczeniu krakowskich centrów handlowych

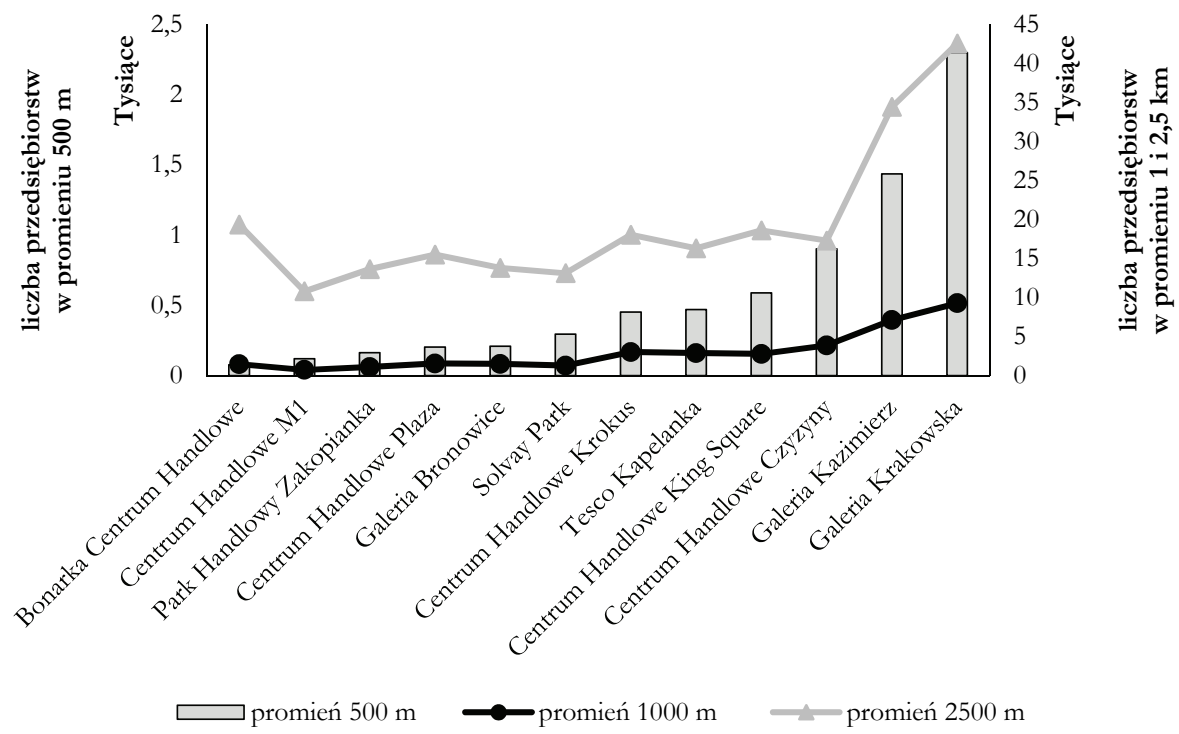

Źródło: opracowanie własne.

W naturalny sposób najwięcej przedsiębiorstw zarówno w bezpośrednim otoczeniu, jak i w tym dalszym stwierdzono w Galerii Kazimierz i Galerii Krakowskiej, położonych w centrum miasta. Wysoką liczbę przedsiębiorstw w bezpośrednim otoczeniu również odnotowało Centrum Handlowe Czyżyny, przy jednoczesnej, bardzo niskiej w stosunku do wymienionych wcześniej obiektów, liczbie przedsiębiorstw w dalszym otoczeniu.

WYKRES 3. Procentowy udział sumy liczby przedsiębiorstw w poszczególnych okręgach w stosunku do całego miasta

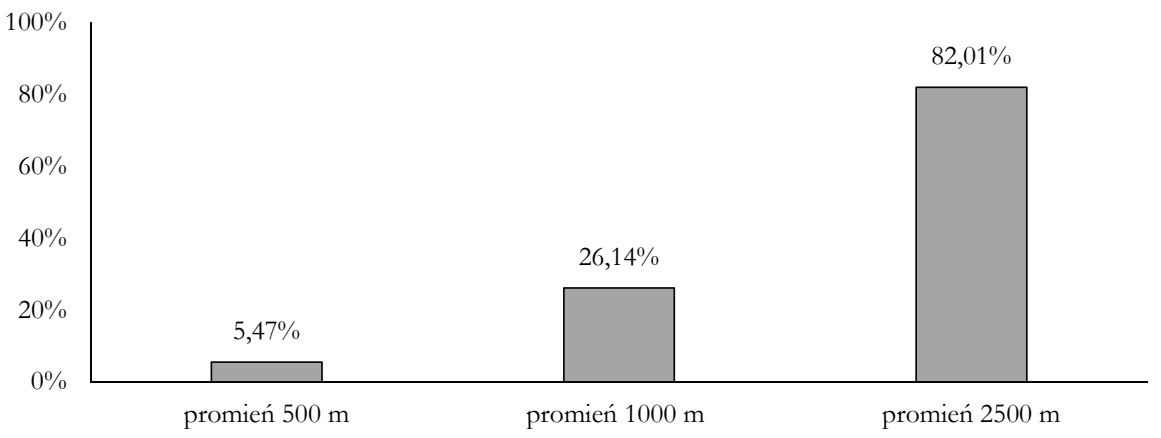

Źródło: opracowanie własne. 
Pośrodku zestawienia znajdują się trzy centra handlowe, tj.: Krokus, Tesco Kapelanka i King Square, posiadające w swoim bezpośrednim otoczeniu znacznie więcej podmiotów gospodarczych, jednak o wciąż niewielkiej ich liczbie w średnim i dalszym otoczeniu.

\section{Weryfikacja hipotezy badawczej}

Zbadaniu profilu gospodarczego otoczenia krakowskich centrów handlowych, posłużył podział gospodarki na sekcje według PKD 2010. Do weryfikacji hipotezy badawczej wykorzystano te sektory gospodarki narodowej, których profil działalności jest zbliżony do usług świadczonych przez współczesne galerie handlowe, czyli:

- $\quad$ sekcja G (handel hurtowy i detaliczny, naprawa pojazdów samochodowych, włączając motocykle);

- $\quad$ sekcja I (działalność związana z zakwaterowaniem i usługami gastronomicznymi).

W ramach powyższych sekcji funkcjonują następujące działy gospodarki narodowej:

- handel detaliczny, z wyłączeniem handlu detalicznego pojazdami samochodowymi;

- handel hurtowy i detaliczny pojazdami samochodowymi, naprawa pojazdów samochodowych;

- handel hurtowy, z wyłączeniem handlu pojazdami samochodowymi;

- działalność usługowa związana z wyżywieniem;

- zakwaterowanie.

W pierwszej kolejności zbadano ogólną strukturę przedsiębiorstw w otoczeniu centrów handlowych. W ten sposób otrzymano udział procentowy każdej sekcji w całym mieście, a także procentowe udziały w trzech analizowanych okręgach wokół obiektów handlowych (wykres 4.).

WYKRES 4.

\section{Przedsiębiorstwa wokół centrów handlowych według sekcji PKD}

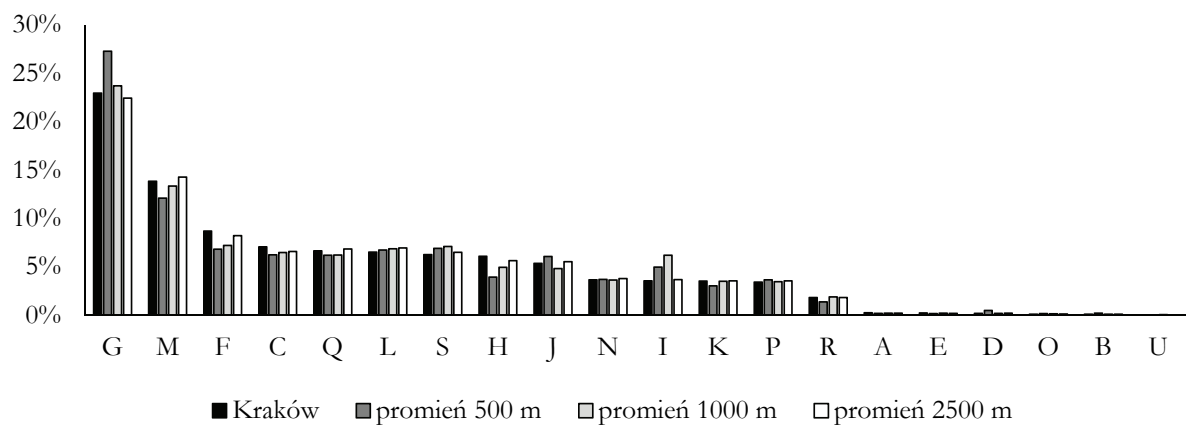

Źródło: opracowanie własne. 
Największa różnica dotyczy sekcji $\mathrm{G}$ - w bezpośrednim sąsiedztwie centrów handlowych $27,30 \%$ wszystkich przedsiębiorstw miało taki profil działalności, podczas gdy w skali całego miasta było to zaledwie 22,96\%. Z kolei, sekcje M (działalność profesjonalna, naukowa i techniczna) i F (budownictwo) cechowały się odwrotna zależnością, w której im dalej od centrum handlowego, tym udział przedsiębiorstw z tych sekcji wzrastał, zbliżając się do średniej z całego miasta. Nietypowy wynik uzyskano dla sekcji I najwyższy udział odnotowano w promieniu $2 \mathrm{~km}$ od centrów handlowych, wyższy niż w bezpośrednim sasiedztwie i zdecydowanie wyższy niż w promieniu $5 \mathrm{~km}$ oraz w skali całego miasta $(6,17 \%$ wobec $4,95 \%)$.

Do dalszej analizy wykorzystano dane jedynie o przedsiębiorstwach z sekcji: G i I, $\mathrm{z}$ dalszym podziałem na działy w ich obrębie. Ich lokalizację prezentuje rysunek 3 .

RYSUNEK 3.

\section{Lokalizacja przedsiębiorstw w otoczeniu centrów handlowych}

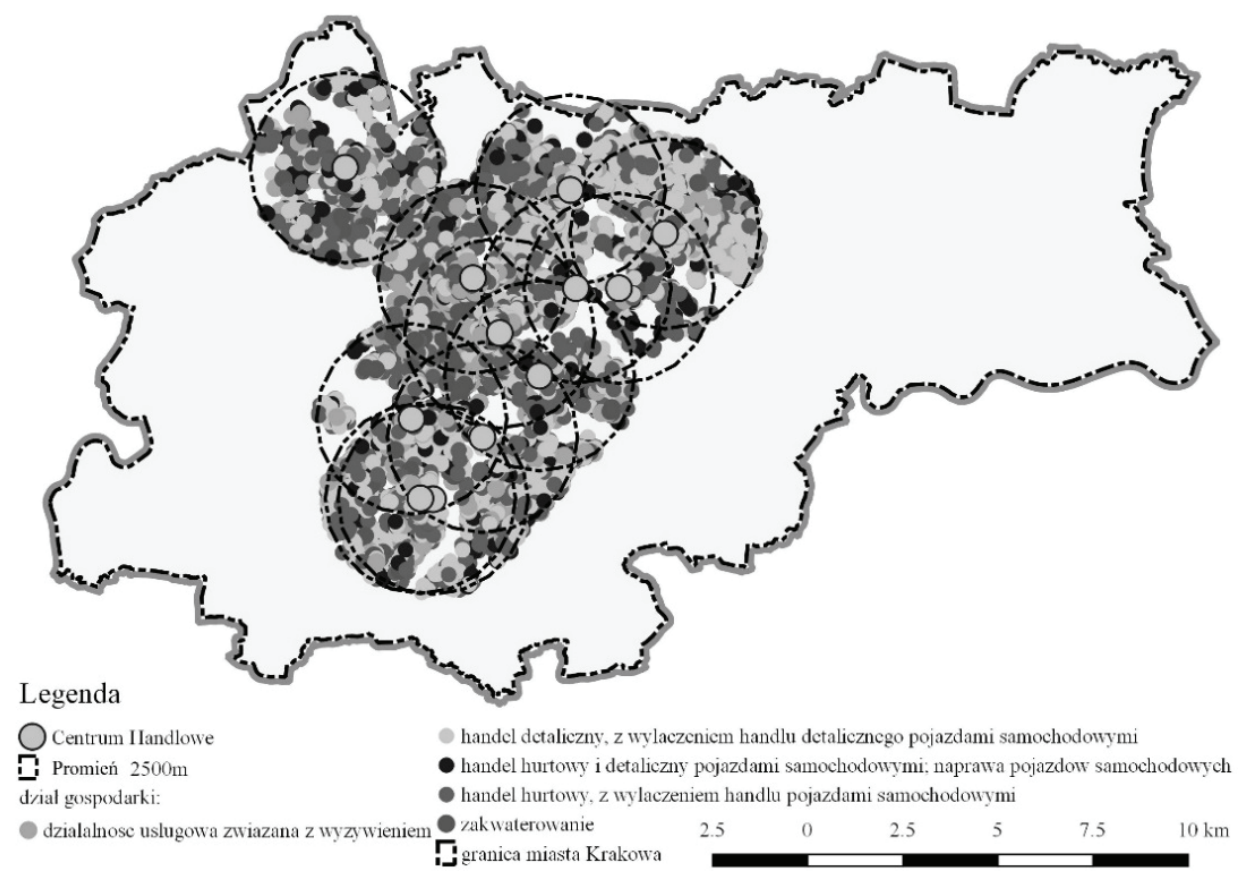

Źródło: opracowanie własne.

W porównaniu uwzględniono udział przedsiębiorstw ze wszystkich wybranych działów gospodarki w trzech okręgach oraz w całym mieście (wykres 5.). Widoczny był wyższy udział wszystkich rodzajów przedsiębiorstw, poza handlem pojazdami samochodowymi. W promieniu $500 \mathrm{~m}$ od analizowanych obiektów można było zaobserwować wyraźnie wyższy udział przedsiębiorstw zajmujących się handlem detalicznym (16,77\%), znacząco przekraczający wartość średnią dla całego miasta (12,85\%). Zaskakujący jest stosunkowo wysoki udział handlu hurtowego w najbliższym otoczeniu, jednak przede 
wszystkim wynikało to z lokalizacji części centrów handlowych na obrzė̇ach miasta przy głównych drogach, zatem w lokalizacji atrakcyjnej również dla wszelkiego rodzaju hurtowni.

WYKRES 5.

\section{Zróżnicowanie przedsiębiorstw sektora I i G w okręgach oraz całym mieście}

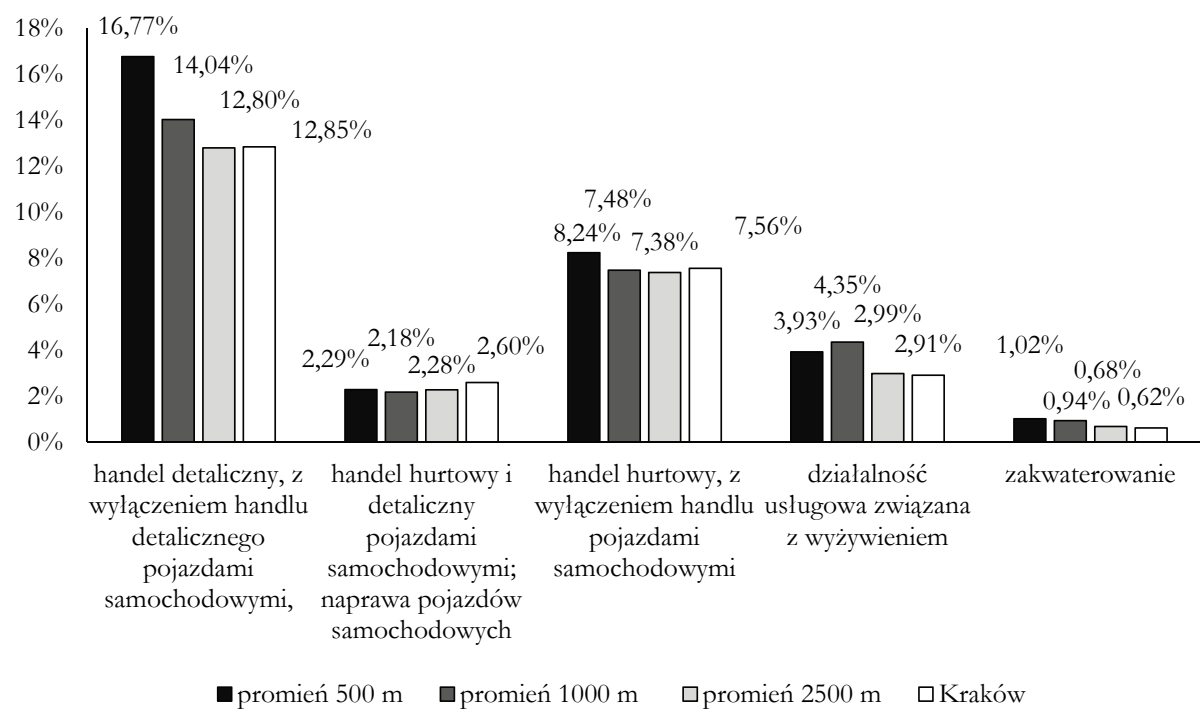

Źródło: opracowanie własne.

Bardzo wysoki udział przedsiębiorstw gastronomicznych w promieniu $1000 \mathrm{~m}$ od analizowanych obiektów może wskazywać na lokalizację restauracji nie w bezpośrednim sąsiedztwie nowoczesnych centrów handlowych, ale w otoczeniu o bardziej tradycyjnym charakterze, czy to w bezpośrednim centrum miasta, czy to przy zabytkowych ulicach Krakowa.

Przeprowadzona analiza dowiodła, że w bezpośrednim otoczeniu centrów handlowych można zauważyć wyraźnie większy udział przedsiębiorstw handlu detalicznego, a w promieniu $1000 \mathrm{~m}$ również gastronomicznych. To natomiast potwierdza postawioną na początku hipotezę. Oznacza to, że nie tylko centra handlowe, lecz także ich otoczenie cechuje się znaczną koncentracją przedsiębiorstw handlowo-usługowych, nastawionych na zaspokajanie konsumpcyjnych potrzeb mieszkańców i turystów.

\section{Podsumowanie}

Celem artykułu było zbadanie otoczenia krakowskich centrów handlowych pod kątem ich wpływu na strukturę przedsiębiorstw. Wykorzystano dane o lokalizacji przedsiębiorstw w celu zweryfikowania hipotezy o tym, że w otoczeniu centrów handlowych 
funkcjonuje wyższy odsetek przedsiębiorstw: handlowych, gastronomicznych i hotelarskich niż w pozostałych częściach miasta.

Przeprowadzono analizę z wykorzystaniem narzędzia GIS, która umożliwiła określenie profilu gospodarczego otoczenia centrów handlowych w promieniu 500, 1000 i $2500 \mathrm{~m}$. Dane te, zestawione z wynikami dla całego Krakowa, pozwoliły wskazać szczególne cechy otoczenia krakowskich obiektów handlowych.

Bezpośrednie otoczenie centrów handlowych cechuje się znacznie wyższym udziałem przedsiębiorstw zajmujących się handlem detalicznym oraz zakwaterowaniem, a zarówno w promieniu 500, jak i $1000 \mathrm{~m}$ od analizowanych obiektów można zaobserwować wyraźnie wyższy udział przedsiębiorstw gastronomicznych. Wyniki te przyczyniły się do pozytywnej weryfikacji postawionej hipotezy.

Przedstawiona analiza nie była pozbawiona ograniczeń. Najpoważniejszym z nich był fakt korzystania $z$ danych o podmiotach gospodarczych zarejestrowanych w Krakowie. $\mathrm{Z}$ jednej strony jest to dalece niedoskonały sposób, z drugiej najdokładniejszy, jaki w praktyce można zastosować. Analogicznie do badań nad ludnością na podstawie adresów zameldowania, należy być świadomym, że rzeczywista sytuacja może różnić się od prezentowanej w badaniach ze względu na dużą swobodę w przemieszczaniu się przedsiębiorstw, które mogą być zarejestrowane gdzie indziej, a prowadzić działalność w Krakowie lub też być zarejestrowane w Krakowie, ale działalność prowadzić poza jego granicami (prawdopodobnie znacznie rzadszy przypadek).

Badania z wykorzystaniem dokładnej lokalizacji przedsiębiorstw są stosunkowo mało popularne z uwagi na ograniczoną dostępność danych. Jest to jednak niezwykle cenne źródło informacji na temat przedsiębiorczości. Z racji bardzo złożonego charakteru zagadnienia, prezentowana analiza ma jedynie charakter przyczynkowy, stanowiący wstępne rozpoznanie problemu w Krakowie. Niezmiernie cenne w równej mierze dla naukowego zrozumienia koncentracji przedsiębiorstw, jak i dla praktycznego zarządzania miastem będą dalsze badania nad lokalizacją przedsiębiorstw wokół dużych obiektów handlowych. Wiele informacji mogą dostarczyć analizy o dużym stopniu szczegółowości, poświęcone jednemu obiektowi wraz z otoczeniem, co pozwoli także uwzględnić topografię terenu czy istniejące obiekty infrastrukturalne, a tym samym stworzyć znacznie bardziej szczegółowe analizy przedsiębiorczości w sąsiedztwie centrów handlowych.

Przeprowadzone badania należy traktować z pewną ostrożnością, bowiem analizy nie uwzględniały aspektu czasowego założenia działalności gospodarczej. Autorzy nie wykluczają kontynuacji badań w tym kierunku.

\section{Wkład autorów w powstanie artykułu}

mgr inż. Anna Stec - opracowanie koncepcji, opracowanie metodyki badań, realizacja analiz, opracowanie wyników, prace redakcyjne i uzupełniające - 50\%, mgr Konrad Sarzyński - opracowanie koncepcji, opracowanie metodyki badań, opracowanie wyników, prace redakcyjne i uzupełniające $-50 \%$. 


\section{Literatura}

Backes N., 1997, Reading the shopping mallcity, "The Journal of Popular Culture", no. 31(3), 1-17, https://doi.org/10.1111/j.0022-3840.1997.3103_1.x.

Brzosko-Sermak A., 2015, Turystyka i handel praygraniczny-praykład wschodniego pogranicza Polski, ,Prace Geograficzne Instytutu Geografii i Gospodarki Przestrzennej Uniwersytetu Jagiellońskiego", nr (141).

Budner W. W., 2014, Handel w rozwoju miasta, Wydawnictwo Uniwersytetu Ekonomicznego w Poznaniu, Poznań.

Feinberg R. A., Sheffler B., Meoli J., Rummel A., 1989, There's something social happening at the mall, "Journal of Business and Psychology", no. 4(1).

Heffner K., Twardzik M., 2015, „Miasto w mieście”-V generacja galerii handlowych w przestrzeni polskich miast, „Marketing i Rynek”, nr (8).

Hołuj D., 2015, Samorzqd Krakowa wobec wyzwań metropolitalności, Wydawnictwo Uniwersytetu Ekonomicznego w Krakowie, Kraków.

Książkiewicz S., 2015, Modelowanie pieszej dostepności przestrzeni miejskiej w teorii spacesyntax, [w:] Miasto w badaniach geografów, IGiGP UJ, Kraków.

Makowski G., 2003,Światynia konsumpcii. Geneza i społeczne znaczenie centrum handlowego, Wydawnictwo Trio, Warszawa.

Markiewicz J., 2010, Shopping Tourism of German Consumers in Szczecin and Surroundings in Light of the Latest Research, „Zeszyty Naukowe Uniwersytetu Szczecińskiego”, nr 6.

Mikołajczyk J., 2009, Rozwój centrów handlowych w Polsce, „Zeszyty Naukowe Uniwersytetu Szczecińskiego. Ekonomiczne Problemy Usług”, (529).

Mikołajczyk J., 2012, Kreowanie wartości centrum handlowego. Perspek.tywa interesariuszy, Wydawnictwo Uniwersytetu Ekonomicznego w Poznaniu, Poznań.

Niemczyk A., 2015, Turystyka zakupowa - istota i uwarunkowania jej rozwoju, „Handel Wewnętrzny", nr 3(356).

Pitt M., Musa Z.N., 2009,Towards defining shopping centres and their management systems, "Journal of Retail and Leisure Property", 8(1), 39-55, https://doi.org/10.1057/ rlp.2008.25.

Præ̧estrzeń życia Polaków, 2014, http://www.sarp.org.pl/pliki/1908_53fdc64b b3140pzp_spistresci_1.pdf (data wejścia: 02.05.2017).

Raport o stanie miasta, 2015, https://www.bip.krakow.pl/?dok_id=79963 (data wejścia: 02.05.2017).

Sarzyński K., 2016, Zróżnicowanie poziomu rozwoju gmin zaliczanych do Krakowskiego Obszaru Metropolitalnego, „Świat Nieruchomości”, nr 3 (97).

Kompendium wiedzy o handlu, 2008, M. Słowińska (red.), Wydawnictwo Naukowe PWN, Warszawa.

Tholons 2015 Top 100 Outsourcing Destinations, 2014, http:/ /www.tholons.com/nl_pdf/ Tholons_Whitepaper_December_2014.pdf (data wejścia: 02.05.2017).

Uchwała Nr XV/174/03 Sejmiku Województwa Małopolskiego z.dnia 22 grudnia 2003 r. w sprawie uchwalenia Planu Zagospodarowania Przestrzennego Województwa Małopolskiego. 